\title{
Dansk kvindelitteratur 1885-1920
}

Den nye kvindebevægelse, der sammen med en række andre politiske bevægelser opstod herhjemme omkring 1970, er baggrunden for den stærkt ogede offentlige interesse for kvinders liv og bevidsthed, som har været karakteristisk for 70 'erne. Interessen har bl.a. vist sig i en stigende produktion af bøger - badde skønlitteratur og forskellig faglitteratur - om og af kvinder. På universiteterne er forskningen $i$ kvindeproblemer intensiveret (eller i al fald påbegyndt), sáledes at den nutidige kvindebevægelse efterhảnden ogsả fảr en historisk dimension.

Dette nummer af Kultur \& Klasse rummer analyser af tekster, der alle (bortset fra de kvindesange som den sidste aktikel tager op) har tilknytning til perioden omkring og lige efter århundredeskiftet, en periode hvor kvindekampen konsoliderede sig. Vi skal her indledningsvis opridse de historiske forudsætninger for kvindekampens opkomst og dernæst give et overblik over de temaer og kvindepolitiske positioner, som Amalie Skram, Thit Jensen og Marie Bregendahl skrev om og pá. Analyserne af tekster fra de tre forfatterskaber viser generelt, at de problemer, kvinderne den gang stod med, pà ingen mâde er overvundet i dag. Derfor kan romanerne og novellerne stadig læses og bruges, sâledes som Amalie Skrams to "sindssygeromaner " fornylig er blevet det af Kirsten Thorup og Line Krog i deres TV-spil Else Kant. Dette TV-spil bliver gennemgáet i en artikel, der bl.a. diskuterer, hvordan den ældre kvindelitteratur kan indgà $\mathrm{i}$ kvindefrigørelseskampen $\mathrm{i}$ dag. I den afsluttende artikel om den nye kvindemusik vises en række eksempler pà, hvordan temaerne fra kvindekampens tidlige faser stadig genfindes i nutidens sangtekster.

Til perioden hører ogsa Karen Blixens tidligste litterære produktion. Dets kvindepolitiske indhold er både begrænset og tvivlsomt, men det repræsenterer dog, som analysen af novellen Pløjeren viser, en bearbejdning af kvindepsykologiske problemstillinger om end kun pà et symbolsk niveau og efter alle kunstens regler. 


\section{Den historiske baggrund for kvindekampens konsolidering i perioden}

Fra 1880 'erne slog kapitalismen for alvor igennem i Danmark og blev den dominerende produktionsmàde. Derved ændredes alle væsentlige samfundsforhold gennemgribende: klassestrukturen, produktionsmáden, statens og of fentlighedens struktur. I takt hermed forandredes også de socialisationsinstanser, som formede individet til samfundsmæssigt væsen, og specielt familiens ændringer fik konsekvenser for kvindernes sociale og bevidsthedsmæssige situation. Udviklingen forte bàde muligheder og problemer med sig, hvilket $\mathrm{i}$ bearbejdet form kom til syne i periodens kvindelitteratur.

Tre karakteristiske forhold ved kapitalismen fik særlig stor betydning for kvinderne:

(1) Produktionen blev adskilt fra reproduktionen, således at seksualiteten og borneopdragelsen blev isolerede funktioner og eneste indhold i den nye intimiserede familie, som derved blev udgræenset fra det samfundsmæssige liv. Det skete først $\mathrm{i}$ byerne $\mathrm{og}$ hos borgerskabet, men efter àrhundredskiftet satte udviklingen sig ogsá tendentielt igennem i det agrare smáborgerskab. Kapitalismens stodvise gennemslagskraft hos de forskellige klasser viser sig ogsá i den tidsforskydning, hvormed de kvindelige forfattere debuterede. De intellektuelle mellemlagskvinder fra København kom forst (Amalie Skram), siden fulgte provinsens og landets smaborgerskab (Thit Jensen og Marie Bregendahl).

(2) Samtidig med, at familien intimiseredes og mistede sine direkte produktive funktioner, blev dens medlemsantal indskrænket. Det beted pá den ene side, at mange ugifte kvinder måtte begynde at klare sig selv økonomisk, selv om deres opdragelse og uddannelse slet ikke havde forberedt dem til det, og pá den anden side blev de gifte kvinder stærkere bundet til hjemmet og isoleret sammen med deres børn og tyendet, som efterhånden blev mere og mere fátalligt.

(3) Samfundet undergik en kraftig økonomisk og politisk vakst i liberalistisk retning. Erhvervsstrukturen blev mere differentieret, hvilket skabte arbejde til en del af de ugifte kvinder fra mellemlagene og smaborgerskabet. Ideologisk blev perioden præget af Brandes' moderne gennembrud; ideerne om frihed og lighed, om borger- og menneskerettigheder blev almindeligt udbredte, og den borgerlige offentligheds synspunkter slog ind i familien og pávirkede kvinderne og samfundets holdning til dem. Individueringsprocessen, som både var en folge af og en forudsætning for den politiske udvikling, beted, at kærligheden blev et bærende motiv for ægteskabsindgàelse, $\mathrm{i}$ al fald i parternes egen selvforstảelse. Det følelsesmæssige forhold til ægtefællen og børnene blev kernen i især kvindernes selvfølelse og i deres livsforventninger.

Den kapitalistiske udvikling både styrkede og hæmmede kvinderne. De blev 
hæmmet, fordi de blev berøvet deres tidligere produktive funktioner $\mathrm{i}$ familiens erhverv, men de blev styrket, fordi deres samfundsmæssige muligheder med den almindelige vakst blev forøget. Med hold i det borgerlige samfunds egen ideologi lykkedes det kvinderne gennem politisk kamp at skaffe sig stemmeret, at fá del $i$ uddannelsestilbudene $o g$ at overtage en del af mændenes arbejdsfunktioner.

Klassetilhørsforholdene blev afgørende for de enkelte kvindegruppers situation. Det var især borgerskabets gifte kvinder, der blev udelukket fra samfundet og isoleret i familien, mens de ugifte mellemlagskvinders perspektiv blev udearbejde pá linie med mændenes (arbejderklassens kvinder havde aldrig været borte fra arbejdsmarkedet). Også for de selverhvervende kvinder blev adskillelsen af produktion og reproduktion imidlertid afgørende, idet denne adskillelse netop ikke fysisk var mulig at gennemføre for en kvinde, der ogsd skulle have børn. De udearbejdende kvinder overskred den intimiserede familiesfære, men kun pá den máde at de blev dobbeltarbejdende og mátte konkurrere pá to fronter: i erhvervslivet med mændene, der helt unddrog sig de reproduktive funktioner (de var gift, levede i pensionater eller blev passet op af ugifte sestre, tanter, opofrende medre o.lign.), og intimsfæren med de gifte og hjemmegáende kvinder, der kunne bruge al deres tid på deres moder- og elskerindefunktioner. Det beted, at konflikten mellem den borgerlige kvindes samfundsmæssige og familiemæessige funktionsmuligheder kom til at tage sig ud som et valg mellem to forskellige kvindeidentiteter, hvor kærlighedsforventningen, der var et resultat af individueringsprocessen, $i$ denne periode orienterede kvinderne mod primært at identificere sig med moder-og familiefunktionerne. De mellemlagskvinder, der blev selverhvervende, mátte i reglen opgive dele af deres kvinderolle, ligesom de reelt mâtte opgive at blive medre. Kun arbejderklassens kvinder tog fuldt ud del $\mathrm{i}$ badde produktion og reproduktion. De blev ofte, med rette eller urette, beskrevet i den borgerlige kvindelitteratur som seksuelt frie eller direkte tøjleslese, fordi de symbolsk blev bærere af borgerskabets kvinders egne fortrængninger, men samtidig var de de hárdest udbyttede i samfundet. For de kvindelige forfattere stod proletariatets kvinder bàde som udfordringer og skræmmebilleder. Hos Amalie Skram har underklassens kvinder al den seksualitet, som hovedpersonerne mangler, men samtidig kommer de også bestandigt galt af sted; når Thit Jensen afviser den frie kærlighed, er det samtidig klart en afvisning af den sociale déroute. Hos Thit Jensen kommer der en ny generation af kvinder til syne: frikvinderne med uddannelse, politiske meninger og en selvstændig social situation. Til gengæld mener forfatteren, at de må give afkald på den ægte kvindelighed: moderfølelsen og kærlighedens mysterium. 


\section{Kvindelitteraturens funktioner og muligheder i perioden}

For første gang i litteraturhistorien kom kvinderne nu til at spille en rolle. Kapitalismen skabte den frie lonarbejder og løsrev det enkelte individ fra alle feudale bånd. Forfatterne begyndte at skrive deres værker for alle, for det principielt ábne og frie marked, hvor også kvinderne kunne prøve lykken. I begyndelsen skrev mange under pseudonym, men i vores periode trâdte de kvindelige forfattere frem under eget navn. Hvor en professionel forfattervirksomhed tidligere var uforenelig med kvindernes private status (fru Gyllembourg, fru Hauch), dér overskred kvinderne nu deres familiære bindinger, om end ofte under stor modstand (junf. Clara Raphael-fejden, det første eklatante eksempel).

De forbedrcde uddannelsesmuligheder for kvinder gav ikke kun forfatterne rygstød; de medvirkede ogsá til at styrke jeg-folelsen hos den enkelte kvinde og fremmede derved opkomsten af et bredt marked for individuelt konsum af bevidsthedsprodukter, der talte ind $\mathrm{i}$ kvindernes ændrede forventninger til livet. Inden for visse rammer betod samfundsudviklingen ligeledes oget personlig frihed (den religiese og politiske tvang mindskedes) og dermed en friere meningsdannelse, som stimulerede litteraturen og herunder kvindelitteraturen.

Dansk Kvindesamfund var blevet stiftet i 1871, og kampen for valgretten førtes stærkest i tiáret op mod 1915, hvor den blev vedtaget. Men perioden var generelt præget af en stærk kvindebevægelse pá mange niveauer. De kvindelige forfattere skal forstås i sammenhæng med denne kvindebevægelse, som de hentede inspiration fra, og hvis problemkomplekser de i høj grad tog op. Amalie Skram udsendte sin første bog som et indlæg i den store sadelighedsfejde $\mathrm{i}$ 80'erne, og Thit Jensen rejste rundt som agitator for DK. Foreningens medlemmer og sympatisører udgiorde en del af den offentlighed, som forfatterne skrev op imod. Pả landet var højskolerne førende i bestræbelserne pá at skabe en agrar småborgerlig offentlighed, og Marie Bregendahls forfatterskab má forstás pá baggrund af denne bevægelse. Stadig flere samfundsmæessige områder blev integreret $i$ den borgerlig offentlighed, og med kvindelitteraturens gennemslag blev også den specifikt kvindelige erfaringsverden fra intimsfæren âbnet for debatten i offentligheden.

Kvindebevægelsen var bredere, end litteraturen lader ane, og den rummede meget mere, end man fár indtryk af ved at lese de romaner og noveller, som bliver behandlet i denne sammenhæng. Der blev gjort (undertiden vellykkede) forsøg pá at fagorganisere arbejderkvinderne; en del kvinder blev aktive i de politiske kampe og gik ind i partierne. Kvindebevægelsen blev băret frem af kvinder, der i høj grad havde erfaringer uden for intimsfæren. Nár mange af disse erfaringer $i k k e$ kom med i litteraturen, var det, fordi mediet særligt egnede sig til bearbejdningen af de bevidsthedsmaessige konsekvenser af ændringerne i kvindernes forhold: skønlitteraturen forcuserer traditionelt pa psykologiske 
problemstillinger! Periodens kvindebevægelse rettede sig ikke kun mod den psykologiske frigørelse af kvinderne, men i højere grad mod den økonomiske og politiske. Kvindelitteraturens særlige rolle i den bevægelse blev da at analysere og fremstille de modsætninger i kvinderollen, som udviklingen medferte. Ofte blev resultatet, at teksterne grelt og bittert afslørede problemerne og begrænsningerne $\mathrm{i}$ kvindernes situation, uden at de med samme styrke kunne pege på brugbare alternativer eller give handlingsanvisninger. Både hos Amalie Skram, Thit Jensen og Karen Blixen ligger lesningen $i$ et bedre familieliv, og hos Marie Bregendahl skal dette familieliv ogsá danne rammen om produktionen. Som gárdmandsdatter havde hun gjort de sidste levende erfaringer med fra en produktionssammenhæng, hvor kvindernes produktive funktioner endnu havde en familie- og samfundsmæssig nødvendighed, og det er på baggrund heraf, at hendes utopi om et anderledes og mere helt kvindeliv skal forstås.

\section{Hovedtemaer $i$ de analyserede tekster}

I artiklen om Amalie Skram behandles den del af forfatterskabet mellem debutromanen Constanc Ring (1885) og de to ssindssygeromaner« (1895), som har ægteskabet og kvindeidentiteten som tema. Artiklen viser, at Amalie Skrams indsats i de første romaner hovedsageligt bestod i nærgående beskrivelser af den ulige, kønsspecifikke seksualudvikling, der var typisk for perioden. Ingen af hendes mandlige og kvindelige hovedfigurer finder hinanden $\mathrm{i}$ lykkelige og harmoniske forhold, fordi deres behov ikke passer sammen. Borgerskabets mænd og kvinder blev opdraget til at gifte sig med hinanden, men de samfundsmæessige krav til den borgerlige familie viste sig sidenhen at stá i vejen for tilfredsstillelsen af dens medlemmers personlige følelsesmassige og driftsmæssige behov. Kvinderne lærte at fortrænge deres aktive seksualimpulser i en sådan grad, at frigiditet ofte blev resultatet, men fortrængningen var nødvendig, hvis de skulle kunne udholde livet i den indelukkede intimsfære. De lærte også at kompensere for følelserne af mindreværd gennem moderskabet. Den meget autoritære opdragelse, mændene var underkastet, satte til gengæld hos dem en for kraftig fortrængning af de tidlige libidinese moderbindinger igennem, săledes at de efter puberteten stod med et opsplittet følelsesliv, der forhindrede, at deres ægtefæller ogsá kunne blive deres seksualobjekter; resultatet var det kendte madonna/luder-kompleks. Den borgerlige familie blev etableret, men det skete pá bekostning af dens medlemmer.

Amalie Skram analyserede den ægteskabelige tvang på en sådan måde, at mændene og kvinderne fremstod som selvstændige, men forskellige individer med hver deres behov og specifikke karakterstrukturer. Hun satte ikke ægte- 
skabets problem som et spørgsmál om kvindernes evne til at tilpasse sig; det havde ellers tidligere været traditionen (junf. atter fru Gyllembourg). Tværtimod stod hun fast pá kvindernes egenart og deres ret til at leve et liv i overensstemmelse med den, uden at hun derfor oversá det modsætningsforhold, som kvinderne kom til at stá $\mathrm{i}$ til deres mænds og omverdenens forventninger til dem. Idet hun beskrev mænd og kvinder som forskellige personligheder, kom hun til at problematisere både kvinderollen og mandsrollen. Hendes tekster stillede indirekte spergsmálet, om manden kunne have patent pá at repræsentere det menneskelige slet og ret, $\mathrm{og}$ hun rejste ligeledes spørgsmálet om, hvordan ægteskaber og familier kunne etableres mellem mennesker, der havde sâ divergerende ønsker og forventninger til tilværelsen.

I Constance Ring mener hun, at problemerne ligger dels i mandens dobbeltmoral, dels i kvindens uvidenhed og frigiditet. Romanen er skrevet med det fromme hăb underneden, at de to ken begge kunne ændre sig (mảske gennem opdragelsen) og tilpasse sig et ikke nærmere bestemt fælles menneskeideal.

I Professor Hieronimus og Pd St. Jergen er hun imidlertid näet frem til den i al fald ubevidste indsigt, at modsætningerne når helt ind i selve kvindeidentiteten. Else Kant bryder sammen, fordi hun ikke både kan udove sin kunst (hun maler) og passe sine ægteskabelige forpligtelser; hustrurollen kan ikke varetages tilfredsstillende af en kvinde, der samtidig prøver at være aktiv uden for hjemmet. Det, Amalie Skram reelt beskriver, er selvfølgelig de psykologiske konsekvenser af den samfundsmæssige adskillelse af produktion og reproduktion, men hun havde ikke muligheder for at gennemskue, at de bevidsthedsmæssige modsætninger, Else lider under, havde deres materielle baggnund i produktionsforholdene. Derfor havde hun heller ikke nogen strategi for bekæmpelsen af dem. Else Kant bryder sammen, fordi modsætningerne i hendes situation simpelthen ikke lod sig forsone, sádan som samfundet og ægteskabet sá ud.

Thit Jensen tog i sit forfatterskab ogsá fat pá spaltningen af kvindeidentiteten. I Erkenvandring (1907), som bliver analyseret i denne sammenhæng, kritjseres borgerskabets traditionelle kvindeopdragelse for ikke at være tidssvarende og lære kvinderne det fornødne. Opdragelsen lærte kvinderne at føre hus for velhavere, men mange af dem blev »dårligt « gift og måtte selv skaffe til hjemmets underhold; hovedpersonen, Eleonora, går nærmest i hundene, fordi hendes mand ikke sørger for hende, og hun ikke har lært at sørge for sig selv (i førsteudgaven myrder han hende helt konkret). I slutningen af romanen viser Thit Jensen, at en ny og bedre udrustet kvindegeneration er ved at vokse frem, frikvinderne kalder hun dem. Det er borgerskabets og mellemlagenes dotre, der kommer ind og godt i vej i uddannelsessystemet, bliver jurister, tandlæger osv. De bliver økonomisk selvstændige, men pá bekostning af deres kvindeidentitet, deres seksualitet og muligheden for moderskab.

I analysen af romanen bliver det påpeget, at Thit Jensens kritik af kvindesitu- 
ationen langt hen hviler pá et ubearbejdet kærlighedsideal. Hendes kritik retter sig noget ubestemt mod det samfund og de mænd, som adelægger kvinderne, men den føres ikke igennem til det borgerlige samfunds eget kvinde- og kærlighedsideal, som Thit Jensen tværtimod kan siges at videreudbygge og kvalificere. Romanen følger en gruppe unge piger, som alle klarer sig dàrligt; den smukkeste og rigeste af dem dør tidligt af svindsot, sá oplægget synes at erklære det ideale ægteskab for umuligt. Men i romanens anden del ser vi, hvor skidt det gàr, nàr en kvinde uden kvinderollens attributter: skønhed og fravær af materielle forpligtelser skal prove at klare for sig selv og sine børn; hun ender med at afgive sit mindste barn til et børnehjem. Og hvis selvstæendigheden săledes begynder at true moderskabet, má den forkastes; det bliver uvægerligt romanens konklusion. Som helhed lægges kvindeidentiteten i moderkarligheden, og der er tendenser til at sætte denne moderkærlighed generelt som det højeste i livet. Derfor fremtår manden ogsá som et kvalitativt reduceret menneske. Hans individualisme og selvtilstrækkelighed konfronteres med hendes omsorg for afkommet og evne til at ofre sig, og kvindeligheden bliver romanens ideal.

Den samme konklusion om end i en noget anden form findes i Marie Bregendahls novelle, Hanne ved Hejen (1918). I modsætning til de to andre forfattere havde Marie Bregendahl sin erfaringsbaggrund på landet. Konflikten mellem familie og produktion fár derfor en særlig udformning hos hende. I store dele af forfatterskabet tematiseres den som en Maria/Martha-konflikt, hvor det erotiske aspekt og kvindens omsorgsfunktioner ikke kan forenes, når vareproduktionen bliver dominerende. Den personlig intellektuelle og følelsesmæssige frigørelse, som det agrare småborgerskabs kvinder gennem højskolerne var blevet orienteret imod, blev i endnu højere grad end for borgerskabets kvinder fikseret i forventningen om det totale kærlighedsfællesskab, fordi andre sociale kanaler for selvrealisering end ægteskabet og husmodertilværelsen var endnu sparsommere inden for landbruget end $i$ byernes borgerskab.

Hanne ved Hejen ender i modsætning til teksterne af Amalie Skram og Thit Jensen positivt. Den munder ud i en utopi, hvor et kvindefællesskab pá tværs af generationerne bliver Hannes følelsesmæssige forankring, samtidig med at fællesskabet udfolder sig omkring produktive funktioner i en landbrugsbedrift. Hos Marie Bregendahl kan produktion og reproduktion altså forenes i den utopiske vision, fordi hun selv var fra landet, og fordi landbruget var det eneste erhverv, hvor denne enhed endnu reelt var mulig og for ikke sá lang tid tilbage havde været det almindeligste. Men utopien præges af regressive træk.

Af de tre forfattere kommer Marie Bregendahl sáledes nærmest til praktiske, okonomiske forstillinger om, hvordan tilværelsen kunne blive en anden og mindre ødelæggende for kvinderne. Hun går ogsả længst i retning af beskrivelsen af et menneskeligt arbejdsmæssigt og følelsesmæssigt fællesskab mellem udelukkende kvinder. Hanne flytter hjem til sin bedstemor efter sit mislykkede 
ægteskab, og hun fár tilfredsstillet alle sine behov der. Men ogsá pá det psykologiske niveau viser utopien sig at være regressiv. Gennem beskrivelsen af bedstemoderens tre ægteskaber oprulles en udvikling, hvor kvinden fjerner sig fra den ødipale faderbinding og ender med at elske sin mand som sit barn. Beskrivelsen af den gamle Hannes forhold til sin sidste og langt yngre ægtemand viser Hanne som den stærkeste pá alle punkter, den aktive, skabende, moderlige. Manden og det mandlige er blevet opsuget af den stærke kvindelighed. Indholdet af utopien i novellen viser sig at være regression til forestillingen om den falliske moder og en narcissistiske fikseret omverdensforstäelse.

Ved en sammenligning af de tre forfatterskaber er det iøjenfaldende, at den mandlige modpol i kvindeuniverserne andrer sig meget fra Amalie Skram til Marie Bregendahl. Hos Amalie Skram er manden den stærke, autoritære, undertrykkende kraft. Hans styrkeposition er arsagen til kvindens svaghed; prøver hun at tage kampen op med ham, bliver hun knust (Constance Ring), men hendes karakter er dannet som et modstykke til hans, sá hvis han bøjer af og stiller hende frit, sá længes hun efter ham i hans faderfunktion (Professor Hieronimus). Thit Jensen pendler mellem en beskrivelse af mænd som dyriske og infantile (Aggersgaard i Crkenvandring) og som ideale beskyttere; den forste type fremstilles mest realistisk! Kvinderne elsker og drommer om den ideale mand, men han fär ingen hovedrolle i romanen, et ligeværdigt forhold forbliver et postulat. Det lykkes heller ikke Marie Bregendahl at gestalte et jævnbyrdigt kærlighedsforhold mellem mand og kvinde; mændene trænges nærmest ud af universet. Denne udvikling bort fra den autoritære mandstype modsvarer en parallel samfundsmæssig udvikling i perioden, hvor faderautoriteten blev svækket og abstraheret i familien. Endringerne i fader/mands-karakteren var et resultat af den markedsorienterede produktions stigende overvægt over den gamle selvforsynende husholdning og af de stigende forventninger til ens eget liv, der pá den ene side samlede sig i kærlighedsfascinationen, men pá den anden side fremmede oprøret mod de undertrykkende former, som kærlighedsforholdet antog i det intimiserede parforhold.

Seksualiteten făr ogsá en forskellig form og betydning i de tre forfatterskaber. Hos Amalie Skram er den det problematiske mandlige princip, som både tiltrækker $\mathrm{og}$ frastøder kvinderne. Thit Jensen beskriver den som en frigørende kraft, der dog fører sociale problemer med sig, mens den hos Marie Bregendahl viser sig dødbringende. (Hos Karen Blixen fungerer seksualiteten pá traditionel vis harmoniserende mellem det mandlige og det kvindelige). Generelt stár seksualiteten og forholdet til manden centralt $\mathrm{i}$ alle teksterne. De handler nok om kvindernes fremmedgjorthed i samfundet og produktionen, om deres angst og passivitet og deres háblese oprør og søgen efter alternative livsmuligheder, men det er $i$ det seksuelle/følelsesmæssige forhold til manden, at brændepunktet for modsætningerne i deres situation findes. Gennem ægteskabet kunne kvinderne 
lesrive sig fra deres opvækstmilieu og komme i kontakt med bredere dele af samfundet; derfor kom seksualiteten til at bære en uforholdsmæssig stor del af kvindernes livsforventninger. Men ægteskabet viste sig for kvinderne ikke at være vejen til, men snarere forhindringen for virkeligt at blive samfundsmæessige væesener, dvs. tage del i produktion og offentligt liv pá linie med mændene. Gennem ægteskabet og det seksuelle forhold kunne kvinderne blive mødre og dermed bekræftet i deres internaliserede kvindeidentitet, men ægteskabet viste sig samtidig at medfore undertrykkelse, personlig ydmygelse og somme tider social déroute, alt afhængigt af den mand kvinden havde fáet. Gennem seksualiteten trådte kvinden i kontakt med manden, som p.g.a. sin samfundsmassige styrkeposition på godt og ondt blev hendes skæbne. Denne skæbne viser teksterne fra århundredeskiftet, at kvinden kun kunne undgå, hvis hun opbyggede sin egen verden, baseret pá eksklusivt kvindefællesskab og ikke-kapitalistiske produktionsformer. Manden som den kapitalistiske kraft skulle fjernes.

Dette konfliktfyldte forhold til seksualiteten er et tema, som i dag stảr lige så ulest som dengang. Det varieres da også atter og atter i de kvindesange, som analyseres i dette nummers sidste artikel.

\section{Erfaringer og lesninger}

Mest generelt kan man sige, at kvindelitteraturen i denne periode rummer en kritik af familien som kvindens arbejds- og livssammenhæng. Familien var en halvfeudal rest i et kapitalistisk samfund i voldsom vækst, og denne rest var tilmed klassemzessigt afgrænset, idet proletarfamilierne nærmest var $i$ oplesning. Borger- og småborgerskabets kvinder befandt sig i egen selvforståelse og ogsả reelt som mellem Skylla og Karybdis. Pá den ene side var der den udfoldede kapitalisme, der kunne tilbyde den kvinde, der ville forlade familien, lenarbejde, deklassering og det fuldstændige afkald pá moderskabet, seksuel og økonomisk udbytning, samt de dertil hørende betragtelige psykiske konflikter, nàr kvinderollen skulle omstruktureres. Pà den anden side var der den lukkede patriarkalske familie med umyndiggørelsen, objektgørelsen og eneansvaret for den samfundsmaessigt negligerede børnesccialisering, altså endnu engang seksuel og økonomisk udbytning.

De stærkeste af kvinderne som f.eks. Thit Jensen sá kun én vej frem, nemlig kampen for ligestilling med mændene inden for det kapitalistiske samfunds rammer. Vi kender deres paroler: uddannelse, borgerrettigheder og siden: ligeløn. Men denne lesning var ikke tilstrækkelig, det kan vi i dag se, bl.a. gennem lasning af deres egne skrifter. Hele spørgsmallet om reproduktionenes private karakter hænger uløseligt sammen med den kapitalistiske produktionsmade, og 
selv om det spørgsmál stod centralt for forfatterne, om ikke $i$ deres analyser sá $i$ al fald $i$ deres beskrivelser af kvindesituationen, sá rummer teksterne ingen ansatser (bortset fra de regressive) til overvejelser over lesninger pá det.

Kvinderne kastede skylden for deres undertrykkelse pá de mænd, som de var i direkte kontakt med; forstàligt fordi det reelt var de mænd, der formidlede undertrykkelsen, men ubrugeligt fordi de mænd selv til dels var objektgjorte af kapitalismen. Når man skal forstá, hvorfor en mere omfattende indsigt i samfundsmekanismerne og undertrykkelsens grundlag ikke lod sig afdække hos disse kvindelige forfattere, må familiens ændringer og funktioner inddrages. Vores periode er kendetegnet ved, at den borgerlige familieform efterhánden breder sig til større og større befolkningsgrupper. Hảndværkerne og det agrare smäborgerskab efterlignende den intimiserede borgerlige familie, og visionerne $o g$ forventningerne til livet blev opsuget af drommen om et kvalitativt menneskeligt familiefællesskab uden for arbejdssfæren. Som næunt var arbejderfamilien i delvis opløsning i den tidlige del af denne periode, og det er derfor forståeligt, at de kvalitative krav og onsker $i$ arbejderbevægelsen $i$ første omgang blev centreret om retten til en menneskeværdig tilværelse omkring de helt basale funktioner: spise, drikke, sove, elske, fødes og dø. Det betød, at ogsá for arbejderklassen blev livsperspektivet i hojere grad rettet mod et kvalificeret familieliv end mod socialistiske visioner. De kollektive arbejdssammenhænge havde ringe vægt i sammenligning med familiefællesskabet, og den borgerlige kvindekamp kunne derfor ikke finde støtte i udfoldede socialistiske teorier. Familien viste sig smidig og tilpasningsdygtig. Lonarbejderidentiteten havde endnu ikke fortrængt slægtsfolelse og traditionsbundethed.

\section{Hvad siger den tids kvindelitteratur os $i$ dag?}

Beskæftigelsen med den tidlige kvindelitteratur overleverer os primært historisk viden og kamperfaringer. Beskrivelserne af den højborgerlige familie hos Amalie Skram og familieformernes ændringer hos Thit Jensen og Marie Bregendahl lzerer os om vore egne familieformers historie, og vi kan gennem den forsege at gennemskue, hvilke af familiens funktioner der kan ændres, og hvilke der har vist sig særligt modstandsdygtige over for samfundsmæessige forandringer.

Vi ved, at kvinder i dag kan fá uddannelse, komme ud pá arbejdsmarkedet, stemme til folketingsvalg, blive regeringsmedlemmer, direktører, buschaufforer, politibetjente, rektorer osv., uden at de derfor nedvendigvis fảr gjort op med deres traditionelle, patriarkalske hjemmeliv. Vi ved, at seksualiteten har fáet et videre spillerum, og at familien har overlevet det ogsá. I dag kan en kvinde faktisk være både mor, lonarbejder og seksuelt aktiv, hvis hun kan holde til det. 
Samfundet har lukket sine tre sfærer op for kvinderne, men under forudsætning af, at de ikke blander tingene sammen. Kvinden skal være lønarbejder på jobbet, politisk individ i offentligheden og mor og seksuelt vasen i familien, og hun skal i modsæetning til manden arbejde pá fuld kraft alle tre steder, hvis hun vil klare sig. Dertil kommer, at de kræfter, hun skal bruge de forskellige steder, er forskellige og modsiger hinanden. Kapitalismen forhindrer ikke kvinderne $\mathrm{i}$ at være med, men de skal deltage pả dens præmisser. Reproduktionens private karakter bliver der sảledes ikke rokket ved; socialiseringen af børnene bliver kun overtaget af samfundet $i$ det omfang, modrene skal frigøres som arbejdskraft, og bornene kvalificeres til bestemte arbejdsfunktioner. Bliver arbejdslesheden for stor, ser man også det praktiske $\mathrm{i}$, at kvinderne helliger sig familien. Kvindefrigørelse forstået som mænds og kvinders lige deling af det produktive og det reproduktive arbejde og en samfundsmæessiggørelse af begge dele, har vist sig at være meget vanskelig at realisere inden for kapitalismens rammer.

De kamperfaringer, teksterne rummer, er bàde positive og negative. Undertrykkelsen og nederlagene afsatte utopiske forstillinger hos forfatterne, men hvor disse forstillinger blev konkretiseret (som hos Marie Bregendahl) fik de et reaktionært udseende. Den tilgrundliggende drom om at frigøre sig bevaredes imidlertid i utopien, og den kan vi $\mathrm{j}$ dag hente frem og fá styrke fra. Else Kant fik ikke lest sine poblemer pả Sct. Hans; analysen af »sindssygeromanerne« viser, at hun riærmest blev retableret i sin kvinderolle. Men hun oplevede dog glimtvis en følelse af overskridende solidaritet og fællesskab med de andre kvindelige patienter, og den følelse kan vi i dag med støre eller mindre ret gribe gennem romanen og give ny betydning. På Amalie Skrams tid var kvindebevægelsen ikke stærk nok til at støtte kvinderne i en vidtgàende kamp for selvstændighed; det var der helt enkelt ikke samfundsmæssig basis for. I dag er den nye kvindebevægelse faktisk en løftestang for mange kvinders frigørelse, så en nutidig bearbejdning af romaneme kan tillade sig at trække kvindefællesskabet frem som et reelt alternativ. Netop sâledes har Kirsten Thorup og Line Krog brugt romanerne i deres TV-spil.

Marie Bregendahls ideer om et lukket kvindefællesskab omkring et mindre landbrug pegede ikke i sig selv fremad, men forsøgene pá at blive subjekt i sit eget liv fremfor vedhæng til en ægtemand var gode nok, og det var også en del af projektet. Oprøret kan vi vedkende os, men ikke altid dets historisk bestemte former.

Af artikleme om kvindesange og Else Kant fremgår det, hvor almene og grundlæggende problemer kvindelitteraturen ved århundredskiftet havde fat $i$, idet de som nævnt kan genfindes i de moderne tekster. Else Kants splittethed mellem sine behov for kærlighedsfællesskabet med ægtemanden og selvstændig social aktivitet kan genfindes hos Joni Mitchell som problemer med at forene behovene for frihed og kærlighed. Og det kvindefællesskab, som på godt og 
Elektronisk version af artikel i 'Kultur \& Klasse 39' (1980), (C) Forlaget Medusa

ondt stod som alternativet hos Marie Bregendahl, har Kirsten Thorup og Line Krog fundet spirene til hos Amalie Skram og fastholdt som det progressive perspektiv i deres TV-spil.

Februar 1979, Lise Busk-Jensen og Inger-Lise Hjordt-Vetlesen. 